\title{
Ptr ToxA Requires Multiple Motifs for Complete Activity
}

\author{
Viola A. Manning, Rachael M. Andrie, Aaron F. Trippe, and Lynda M. Ciuffetti \\ Department of Botany and Plant Pathology, Oregon State University, Corvallis, OR 97331, U.S.A.
}

Received 2 October 2003. Accepted 16 December 2003.

\begin{abstract}
Ptr ToxA was the first proteinaceous necrosis-inducing toxin identified and cloned from the wheat pathogen, Pyrenophora tritici-repentis. How this protein causes necrosis in sensitive wheat cultivars is not known. In an effort to understand the structural features of $P \operatorname{tr} T o x A$ required for induction of necrosis, we employed a combination of site-directed mutagenesis and peptide inhibition studies. Mutagenesis was carried out on conserved motifs within the active domain of Ptr ToxA. Proteins with mutations of potential casein kinase 2 phosphorylation sites but not protein kinase C phosphorylation sites have significantly reduced activity. Additionally, mutations in a region with high homology to amino acids surrounding and including the RGD cell attachment motif of vitronectin result in proteins with significantly less activity than Ptr ToxA. The importance of the vitronectin-like motif was confirmed by a decrease of Ptr ToxA-induced activity when coinfiltrated with peptides corresponding to amino acids within this motif. Reduction in Ptr ToxA activity by competition with mutant proteins demonstrates the necessity of multiple motifs for Ptr ToxA activity.
\end{abstract}

Additional keywords: integrin, host-selective toxins, tan spot.

Pyrenophora tritici-repentis, the causal agent of tan spot of wheat, has been shown to produce host-selective toxins (HST) that elicit disease symptoms on susceptible wheat cultivars (Ballance et al. 1989; Strelkov et al. 1999; Tomas et al. 1990; Tuori et al. 1995). Several HST have been isolated from $P$. tritici-repentis, including Ptr ToxA (Ballance et al. 1989; Tomas et al. 1990; Tuori et al. 1995; Zhang et al. 1997), Ptr ToxB (Strelkov et al. 1998), and Ptr ToxC (Effertz et al. 2002). Other toxins are produced by P. tritici-repentis (Ali et al. 2002; Friesen et al. 2002; Manning et al. 2002; Tuori et al. 1995) but have yet to be characterized. Ptr ToxA (syn. Ptr toxin, Ptr necrosis toxin, and ToxA [Ciuffetti et al. 1998]) was the first fungal host-selective protein toxin to be characterized (Ballance et al. 1989; Tomas et al. 1990; Tuori et al. 1995, Zhang et al. 1997). Both the cDNA (Ballance et al. 1996; Ciuffetti and Tuori 1996) and the gene including the endogenous promoter (ToxA) (Ciuffetti et al. 1997) for Ptr ToxA (hereafter referred to as ToxA) have been cloned. Unlike other HST (Walton 1996; Wolpert et al. 2002), ToxA is a single gene product. The gene for Ptr ToxB (ToxB) (Martinez et al. 2001), another protein HST produced by $P$. tritici-repentis (Strelkov et al. 1998), has also been cloned and characterized (Martinez et al. 2001) and differs from ToxA in that it exists as multiple copies in the genome (Lamari et al. 2003; Martinez et al. 2001, 2004).

Corresponding author: L. Ciuffetti;

E-mail: ciuffetL@science.oregonstate.edu
Purified ToxA infiltrated into leaves of susceptible wheat cultivars elicits severe tissue necrosis (Ballance et al. 1989; Tomas et al. 1990; Tuori et al. 1995; Zhang et al. 1997). Nonpathogenic strains of $P$. tritici-repentis transformed with and expressing the ToxA gene become pathogenic (Ciuffetti et al. 1997). Therefore, ToxA plays a pivotal role in the pathogenicity process of $P$. tritici-repentis on ToxA-sensitive wheat cultivars.

The genetics of the $P$. tritici-repentis-wheat interaction is reminiscent of gene-for-gene type interactions. In classic genefor-gene interactions, a pathogen carries a dominant Avr gene that results in the induction of the resistance response in a plant that carries the cognate resistance gene (Flor 1971). However, in this host-selective toxin variant of gene-for-gene, the interaction between ToxA and its corresponding host gene results not in resistance but susceptibility (Lamari et al. 2003; Wolpert et al. 2002). Therefore, when susceptible wheat cultivars are inoculated with ToxA-producing isolates of $P$. triticirepentis, the result is tan necrosis and disease (Lamari and Bernier 1989, 1991) rather than a hypersensitive response and resistance. The host response to ToxA is conditioned by a single dominant (Lamari and Bernier 1989, 1991) sensitivity locus, Tsnl (Anderson et al. 1999; Gamba et al. 1998), that has been localized to the chromosome arm 5BL (Anderson et al. 1999; Faris et al. 1996; Stock et al. 1996). It remains to be seen if the mechanisms underlying the Avr-induced hypersensitive response are similar to the mechanisms required for ToxAinduced necrosis (Wolpert et al. 2002).

ToxA encodes a pre-pro-protein (Ballance et al. 1996; Ciuffetti et al. 1997). The presence of a signal peptide, i.e., a pre-region, is consistent with secretion of the protein. The proprotein consists of a 4.3-kDa anionic $\mathrm{N}$ domain and a 13.2$\mathrm{kDa} C$ domain (Ciuffetti et al. 1997). The active, secreted form of ToxA isolated from culture filtrates of ToxA-producing isolates is $13.2 \mathrm{kDa}$, as determined by mass spectroscopy (Tuori et al. 1995), and contains an N-terminal pyroglutamate (Tuori et al. 2000). Heterologous expression of the N+C domain of ToxA in Escherichia coli yields protein with a higher specific activity than expression of the $\mathrm{C}$ domain alone. Therefore, the $\mathrm{N}$ domain of the pro-protein appears to be important for proper folding of the mature peptide, i.e., the $\mathrm{C}$ domain (Tuori et al. 2000). The $\mathrm{C}$ domain contains two cysteine residues that also contribute to the function and structure of the protein (Tuori et al. 2000). Other structural motifs include two potential myristoylation sites (Ciuffetti et al. 1997), six potential phosphorylation sites (Ciuffetti et al. 1997; Zhang et al. 1997), and an RGD cell attachment motif (Ciuffetti et al. 1997; Meinhardt et al. 2002; Zhang et al. 1997). Tuori and associates (2000) demonstrated that a mutation of threonine 137, just $\mathrm{N}$ terminal to the RGD motif at arginine 140, leads to decreased toxin activity. Also, a recent study has shown that the glycine and aspartic acid residues of the RGD motif are important for toxin activity (Meinhardt et al. 2002). 
In an effort to determine the importance of the different motifs present in ToxA, we used several approaches. Sitedirected mutagenesis of individual amino acids within conserved motifs of ToxA was used to evaluate the contribution of these motifs to ToxA activity. The importance of the RGD cell attachment motif was further probed by the use of peptides that either contained or did not contain RGD as competitors to ToxA activity. Additional competition experiments between ToxA and mutant forms of ToxA as well as results from peptide competition and site-directed mutagenesis show that multiple motifs are necessary for complete activity of ToxA.

\section{RESULTS}

Construction and expression of mutant forms of Ptr ToxA.

To define potential functional sites of ToxA, a search for conserved protein motifs was performed using the PROSITE

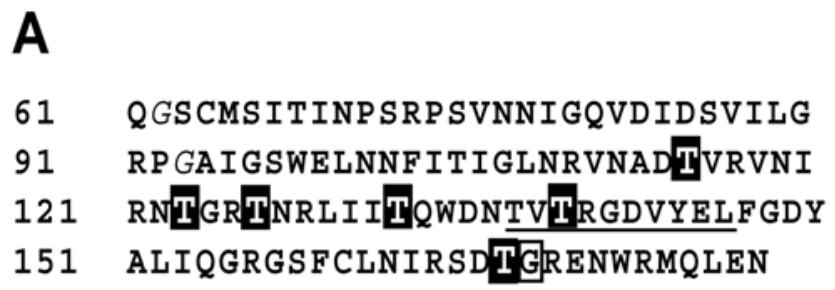

B

ToxA

Vitronectin

1 TVTRGDVYEL

1 QVTRGDVFAL

Fig. 1. Conserved motifs of ToxA. A, Amino acid sequence of mature ToxA. The sequence begins with a pyroglutamate residue. The italicized $\mathrm{G}$ (glycine) residues (amino acids 62 and 93) are consensus myristoylation sites; the boxed white $\mathrm{T}$ (threonine) residues are consensus phosphorylation sites; the underlined residues are a vitronectin-like motif; the $\mathrm{G}$ residue inside the clear box is not within a conserved motif and was included as a control. B, Alignment of the vitronectin-like motif of ToxA and a "consensus vitronectin sequence" around the RGD cell attachment motif of vitronectin. The black-boxed residues are identical, and the gray-boxed residues are conserved between ToxA and vitronectin. database (Sigrist et al. 2002). The search revealed two potential myristoylation motifs (Ciuffetti et al. 1997), six potential phosphorylation sites (Ciuffetti et al. 1997; Zhang et al. 1997), and a potential RGD cell attachment motif (Ciuffetti et al. 1997; Meinhardt et al. 2002; Zhang et al. 1997) (Fig. 1A). The six putative phosphorylation sites are composed of two distinct types (Zhang et al. 1997). Three are potential protein kinase C (PKC) phosphorylation sites (Woodgett et al. 1986), two are potential casein kinase 2 (CK2) phosphorylation sites (Pinna 1990), and one site may be phosphorylated by either type of kinase. The amino acids around the RGD cell attachment motif show homology to an integrin-binding motif of the protein vitronectin (vitronectin-like motif) (Suzuki et al. 1985) (Fig. 1B).

Alanine-substitution mutagenesis of an E. coli heterologous expression vector encoding a His-tagged ToxA fusion protein (Tuori et al. 2000) was used to study the importance of individual amino acid residues to ToxA function. Tuori and associates (2000) demonstrated that ToxA expressed in this system produced tan necrosis in ToxA-sensitive but not ToxA-insensitive wheat cultivars. The heterologously expressed fusion protein (hetToxA) was similar in activity to native ToxA. Table 1 lists the mutations that were made, the sequences of one of the complementary primer pairs that were used for site-directed mutagenesis, and the name of the resultant constructs. Mutated amino acids include: i) threonine residues that could be phosphorylated by PKC or CK2, ii) amino acids of the vitronectin-like motif, including the RGD cell attachment motif, and iii) an amino acid (g168) that is not contained within a known conserved motif and serves as a control for mutagenesis and expression. Proteins were expressed in $E$. coli and were purified to homogeneity (Fig. 2). The expressed protein containing the d142a mutation rapidly degraded after purification (data not shown); therefore, this protein was not evaluated in this study. The t132a mutant protein was also prone to degradation after purification but not to the extent of the d142a mutant protein; therefore, this protein was still included in this study. All of the remaining proteins purify to a single band with a similar mobility to the control ToxA fusion protein (hetToxA), with the exception of the e145a mutation (Fig. 2B).

Table 1. Plasmid names of Ptr ToxA alanine-substitution mutants and the primers used to synthesize the mutants

\begin{tabular}{|c|c|c|}
\hline Mutant & Plasmid name & $5^{\prime}$ sequence of forward primer \\
\hline \multicolumn{3}{|c|}{$\overline{\text { PKC phosphorylation }}$} \\
\hline $\mathrm{t} 115 \mathrm{a}$ & pCVM53 & GCGGTAAACGCCGATGCAGTGCGAGTCAAC \\
\hline $\mathrm{t} 123 \mathrm{a}$ & pCVM54 & CAACATCCGAAACGCCGGCAGGACTAATG \\
\hline t126a & pCVM55 & GAAACACCGGCAGGGCTAATCGCCTCATT \\
\hline $\mathrm{t} 167 \mathrm{a}$ & pCVM57 & CTCGATCTGATGCAGGTCGTGAAAATTG \\
\hline \multicolumn{3}{|c|}{ CK2 phosphorylation } \\
\hline $\mathrm{t} 132 \mathrm{a}$ & pCVM56 & CGCCTCATTATTGCTCAATGGGATAATAC \\
\hline $\mathrm{t} 139 \mathrm{a}$ & pCVM34 & GGGATAATACTGTCGCTCGGGGGGACGTTTATGAG \\
\hline $\mathrm{t} 167 \mathrm{a}$ & pCVM57 & See PKC phosphorylation \\
\hline \multicolumn{3}{|c|}{ Vitronectin } \\
\hline n136a & pCVM19 & ATTACTCAATGGGATGCTACTGTCACTCGGGGGG \\
\hline t137a & pCT79 & Touri et al. 2000 \\
\hline v138a & pCVM21 & CAATGGGATAATACTGCCACTCGGGGGGAC \\
\hline $\mathrm{t} 139 \mathrm{a}$ & pCVM34 & See CK2 phosphorylation \\
\hline r140a & pCVM23 & GGGATAATACTGTCACTGCGGGGGACGTTTATGAG \\
\hline g141a & pCVM25 & GGATAATACTGTCACTCGGGCGGACGTTTATGAGC \\
\hline d142a & pCVM27 & GGATAATACTGTCACTCGGGGGGCAGTTTATGAGC \\
\hline v143a & pCVM29 & CTGTCACTCGGGGGGACGCTTATGAGCTTTTTG \\
\hline y144a & pCVM30 & CGGGGGGACGTTGCTGAGCTTTTTGGTG \\
\hline e145a & pCVM31 & GGGGACGTTTATGCGCTTTTTGGTGATTACGC \\
\hline $1146 \mathrm{a}$ & pCVM32 & GGGGGACGTTTATGAGGCTTTTGGTGATTACGC \\
\hline $\mathrm{f} 147 \mathrm{a}$ & pCVM33 & GGGACGTTTATGAGCTTGCTGGTGATTACGCTTTAATTC \\
\hline \multirow{2}{*}{\multicolumn{3}{|c|}{ С IU⿴囗十 }} \\
\hline & & \\
\hline g168a & pCVM17 & ATACGATCTGATACAGCTCGTGAAAATTGGAGAATGCAGC \\
\hline
\end{tabular}




\section{Activity of alanine-substitution mutants.}

We assessed the ability of alanine-substituted mutant proteins to induce necrosis and chlorophyll reduction in sensitive wheat. Infiltration of control toxin (hetToxA) into sensitive wheat leaves leads to leaf necrosis with a concurrent reduction of total chlorophyll (Fig. 3). The reduction in the amount of chlorophyll at day 2 is proportional to the extent of necrosis at day 2 (Fig. 3). For example, comparison of the activity of hetToxA and the t115a mutant protein shows more severe tissue necrosis at day 2 in the hetToxA-infiltrated leaves than the t115a-infiltrated leaves (Fig. 3B). These results are also reflected in the chlorophyll assay at day 2 (Fig. 3A), in which hetToxA-infiltrated leaves contain less chlorophyll than t115ainfiltrated leaves. Water infiltrated into sensitive wheat leaves results in no necrosis and no loss of chlorophyll (Fig. 3A through $\mathrm{C}$ ). There are no differences in the chlorophyll content of untreated leaves or $\mathrm{H}_{2} \mathrm{O}$-treated leaves (data not shown). In addition to assessing the activity of the alanine-substitution mutants at day 2, the extent of leaf necrosis was also determined at day 5 with the leaf necrosis bioassay (Fig. 3C).

Mature ToxA contains six potential phosphorylation sites (Ciuffetti et al. 1997; Zhang et al. 1997). Threonines 115, 123, and 126 are potential sites for phosphorylation via a PKC-like kinase and threonines 132 and 139 are candidates for phosphorylation via a CK2-like kinase. Either type of kinase can potentially phosphorylate threonine 167 . Heterologously expressed proteins mutated at the putative PKC phosphorylation sites ( $\mathrm{t} 115, \mathrm{t} 123$, and $\mathrm{t} 126)$ were infiltrated into sensitive wheat leaves, and the amounts of chlorophyll and necrosis were measured via chlorophyll assay at day 2 (Fig. 3A) and leaf necrosis bioassay at days 2 (Fig. 3B) and 5 (Fig. 3C). Infiltration of hetToxA or the t123a mutant protein results in necrotic symptoms at day 2 (Fig. 3B) and a comparable reduction of chlorophyll (Fig. 3A). Infiltration of the $\mathrm{t} 115 \mathrm{a}$ or $\mathrm{t} 126 \mathrm{a}$ mutant protein also results in necrosis at day 2 and in the reduction of chlorophyll but not to the extent of hetToxA (Fig. 3A and B). The amount of chlorophyll present after treatment with hetToxA and any of the proteins that contain mutations at potential PKC phosphorylation sites (t115, t123, t126) differed significantly from the amount of chlorophyll present in $\mathrm{H}_{2} \mathrm{O}$-infiltrated controls (Fig. 3A). All proteins whose activity resulted in a chlorophyll content significantly different from that in water-infiltrated leaves at day 2 induce tissue necrosis by day 5 (Fig. 3C). Therefore, all PKC-like mutant proteins appear to retain the ability to induce necrosis, although two of the mutants (t115a and t126a) appear to require more time to achieve necrosis levels similar to that of hetToxA and t123a (Fig. 3B and C).

Whereas mutagenesis of potential PKC-like phosphorylation sites results in proteins with either slightly reduced ToxA activity or activity similar to control toxin, mutagenesis of two of the three potential CK2 sites have a more dramatic effect on ToxA activity (Fig. 3C and F). Infiltration of toxin mutated at either $\mathrm{t} 132$ or $\mathrm{t} 139$ elicits no response as evidenced by chlorophyll content and a lack of necrosis induction that is similar to $\mathrm{H}_{2} \mathrm{O}$-infiltrated controls at day 2 (Fig. 3D and E), whereas infiltration with hetToxA and a protein mutated at $\mathrm{t} 167$ have significant activity, based on chlorophyll content and necrosis at day 2 (Fig. 3D and E). There is slight necrosis visible on t132a mutant-treated leaves at day 5, indicating significantly reduced activity for the $1132 \mathrm{a}$ mutant, while the $\mathrm{t} 139 \mathrm{a}$ mutant protein appears to be completely inactive (Fig. 3F). By day 5, the t167a mutant- and hetToxA-treated leaves show extensive necrosis (Fig. 3F).

The vitronectin-like motif of ToxA includes amino acids 137 through 146 and the RGD cell attachment motif (Fig. 1). We included an additional N-terminal (n136) and C-terminal (f147) amino acid in our mutagenesis studies, to determine if amino acids outside of the vitronectin-like motif might also influence ToxA activity. Glycine $168(\mathrm{~g} 168)$ is not within an identified motif in ToxA (Fig. 1A). Additionally, proteins with arginine 164 mutated to a stop codon, creating a carboxy-terminal truncation that no longer contains g168, are fully active (V. A. Manning and L. M. Ciuffetti, unpublished data). The mutagenesis of this amino acid is therefore unlikely to result in a protein with activity different from that of hetToxA. Therefore, the g168a mutant protein was added to this study as a control protein. The v138a mutant protein shows activity similar to that of the g168a mutant (control) protein as well as to that of hetToxA at day 2 (Fig. $3 \mathrm{G}$ and $\mathrm{H}$ ), with infiltration of any of these three proteins leading to a significant reduction of chlo-

\section{A Phosphorylation domain}

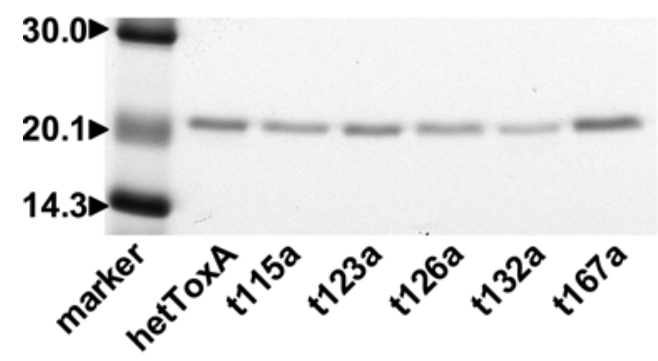

\section{B Vitronectin-like domain}

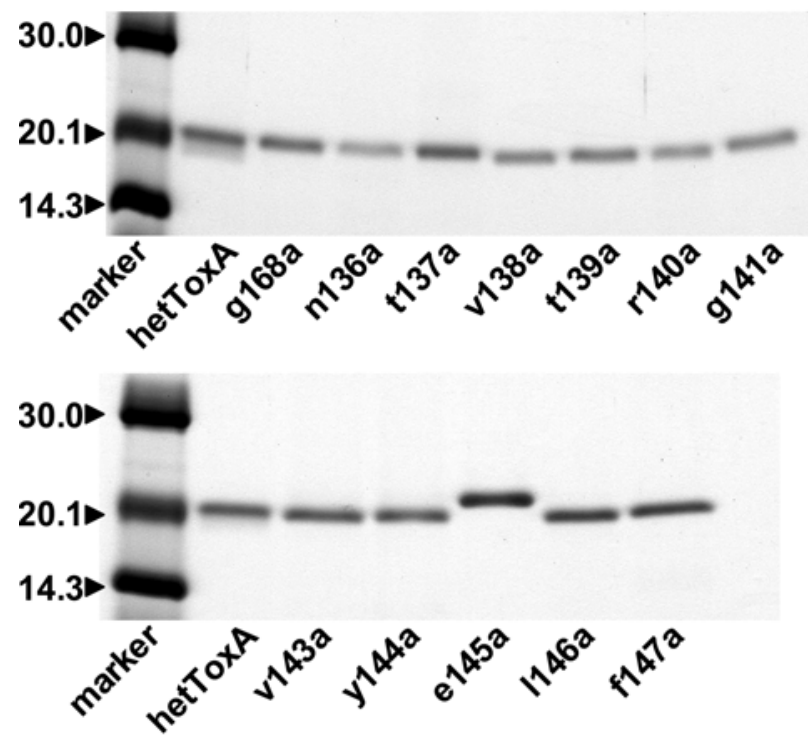

Fig. 2. Sodium dodecyl sulfate-polyacrylamide gel electrophoresis of heterologously expressed and refolded ToxA mutant proteins. Proteins were electrophoresed and detected by a colloidal Coomassie stain. Marker refers to size marker (kDa). A, ToxA fusion protein (hetToxA) and consensus phosphorylation motif mutant proteins. Amino acids t115, t123, and $t 126$ are potential protein kinase $\mathrm{C}(\mathrm{PKC})$ phosphorylation sites, and t132 is a potential casein kinase 2 (CK2) phosphorylation site. Amino acid $\mathrm{t} 139$, also a potential CK2 phosphorylation site, is included in B. Amino acid t167 can potentially be phosphorylated by either a PKC or CK2 kinase. B, Vitronectin-like motif mutant proteins (t137 through 1146). Amino acid g168 is a heterologously expressed control protein. Amino acids n 136 and $\mathrm{f} 147$ are outside of the vitronectin-like motif. Amino acid t139 is both a potential CK2 phosphorylation site and within the vitronectin-like motif. 
rophyll content compared with that of the $\mathrm{H}_{2} \mathrm{O}$-infiltrated control (Fig. 3G). It was predicted and shown that the g168a mutant (control) protein has the same activity as hetToxA (Fig. $3 \mathrm{G}$ through I). Again, the level of necrosis seen at day 2 (Fig. $3 \mathrm{H}$ ) is reflected in the total chlorophyll assay (Fig. 3G), and all toxin treatments that resulted in a significantly lower chloro-

A
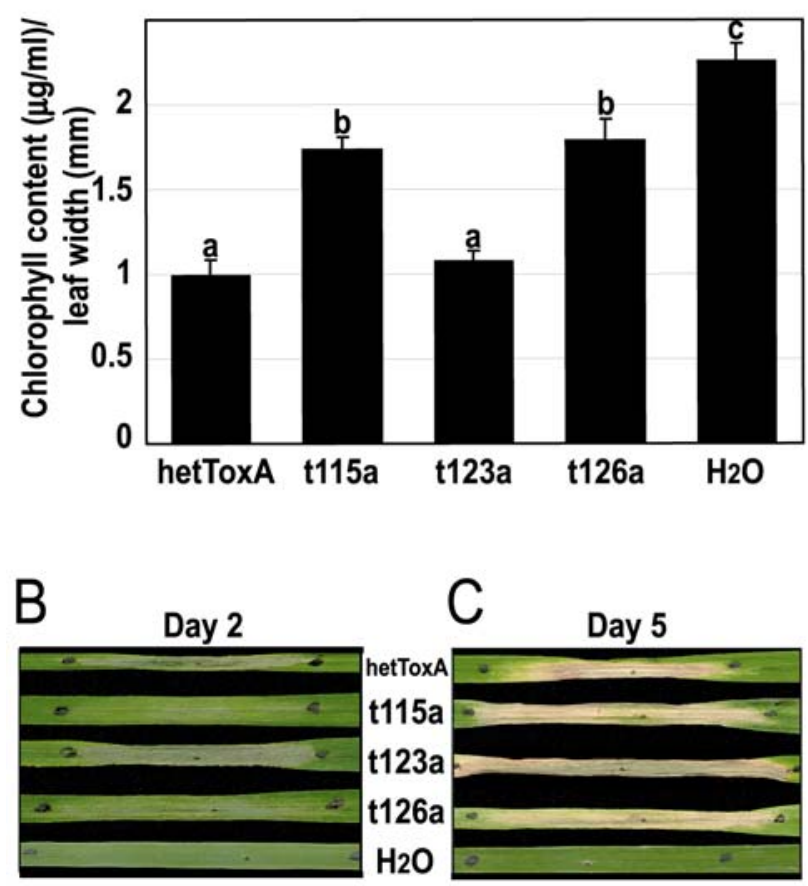

phyll content than did water treatment led to severe tissue necrosis by day 5 (Fig. 3I). The necrosis-inducing activity of the 1146a mutant protein is severely reduced, as only a slight amount of necrosis at day 2 and day 5 is visible in 1146a mutant-treated leaves (Fig. $3 \mathrm{H}$ and I). All other mutant proteins within the vitronectin-like motif, including mutant
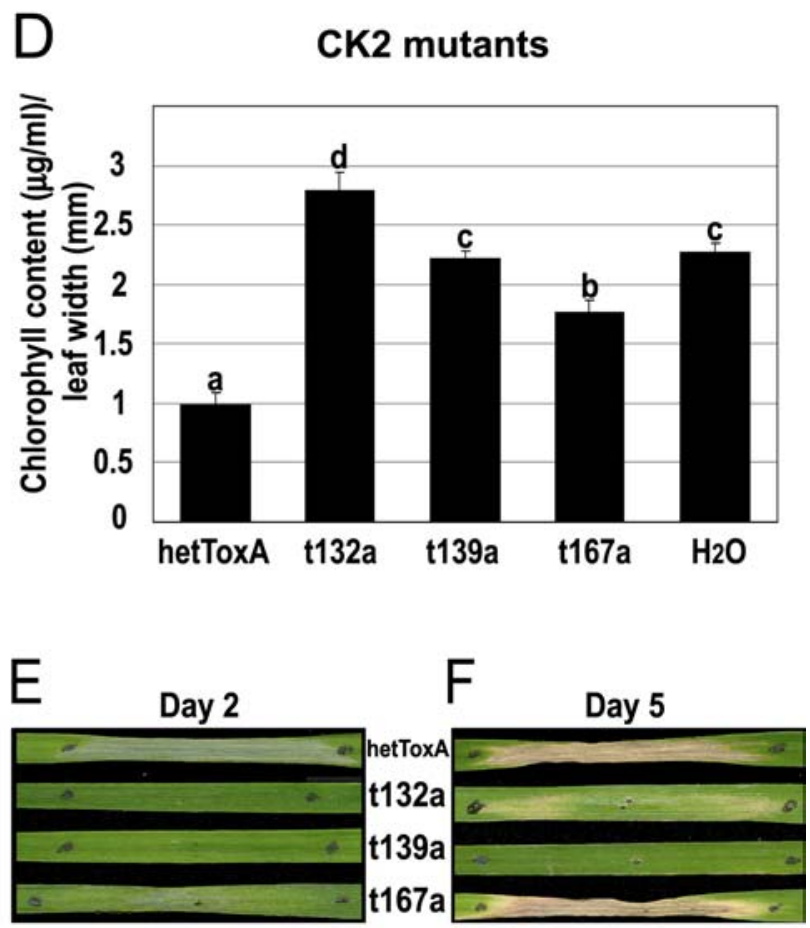

\section{Vitronectin-like mutants}
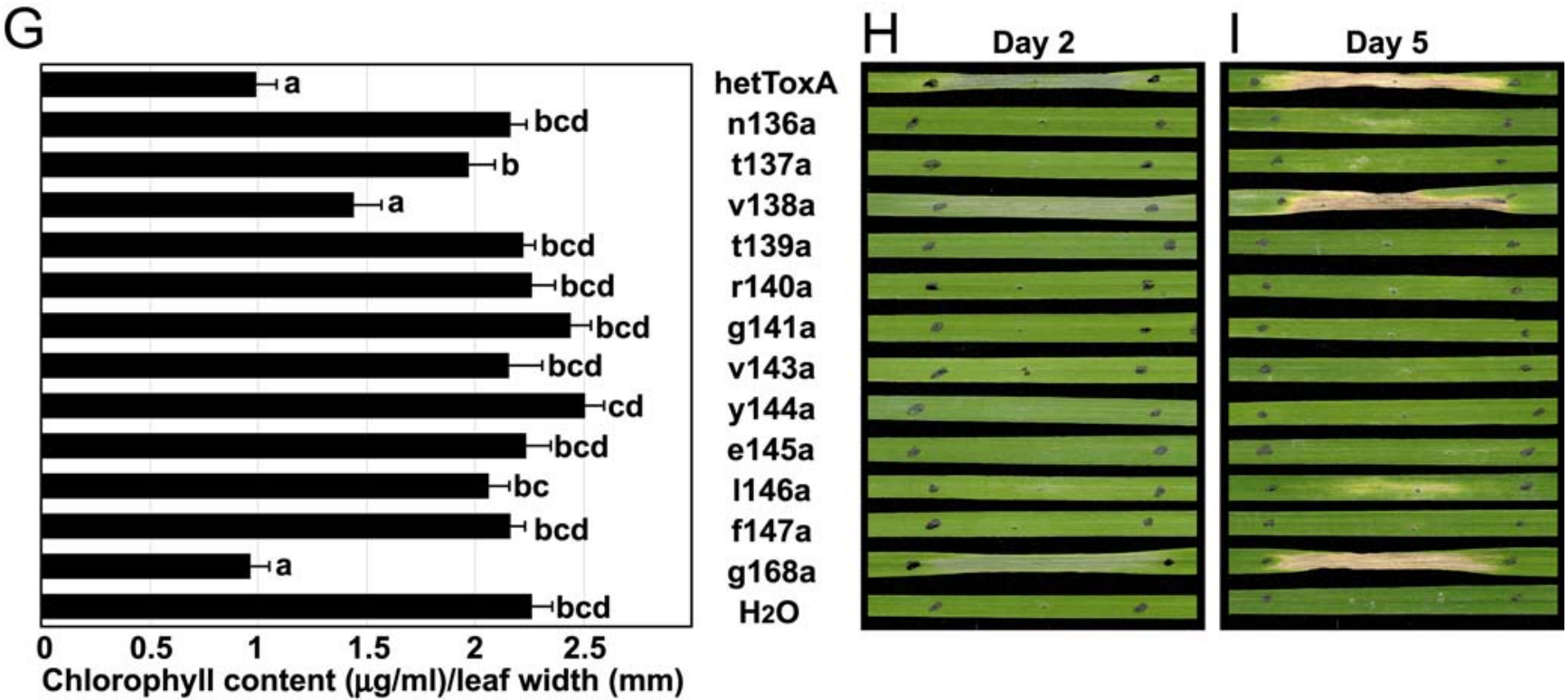

Fig. 3. Activity of ToxA mutant proteins. Sensitive leaves were infiltrated with $2 \mu \mathrm{M}$ of each protein. A, Total chlorophyll assay of ToxA protein kinase C (PKC) mutant proteins at day 2. B, Leaf necrosis bioassay of ToxA PKC mutant proteins at day 2 and $\mathbf{C}$, at day 5 . D, Total chlorophyll assay of ToxA casein kinase 2 (CK2) mutant proteins at day 2. E, Leaf necrosis bioassay of ToxA CK2 mutant proteins at day 2 and $\mathbf{F}$, at day 5 . G, Total chlorophyll assay of vitronectin-like motif mutant proteins of ToxA at day 2. H, Leaf necrosis bioassay of vitronectin-like motif mutant proteins of ToxA at day 2 and I, at day 5 . Means followed by the same letter (within each graph) are not significantly different as determined by Tukey's honestly significant difference test at a $P<$ 0.05 . Error bars represent standard errors. 
A

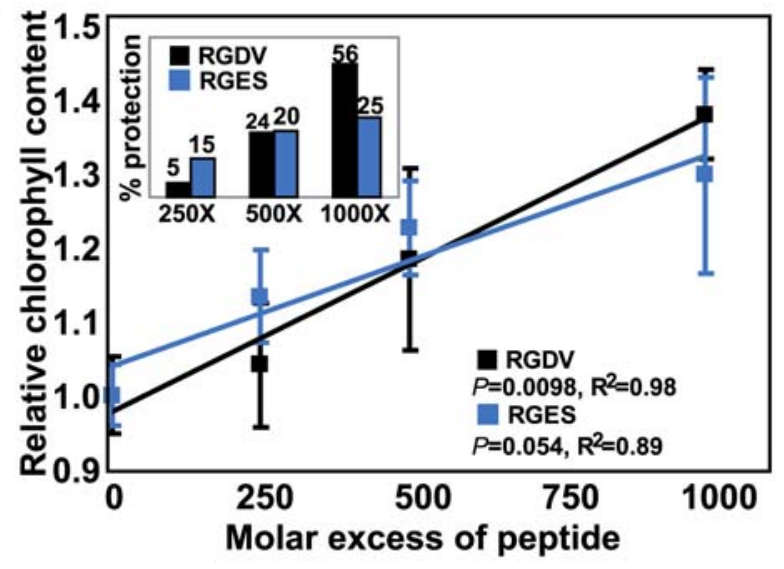

B

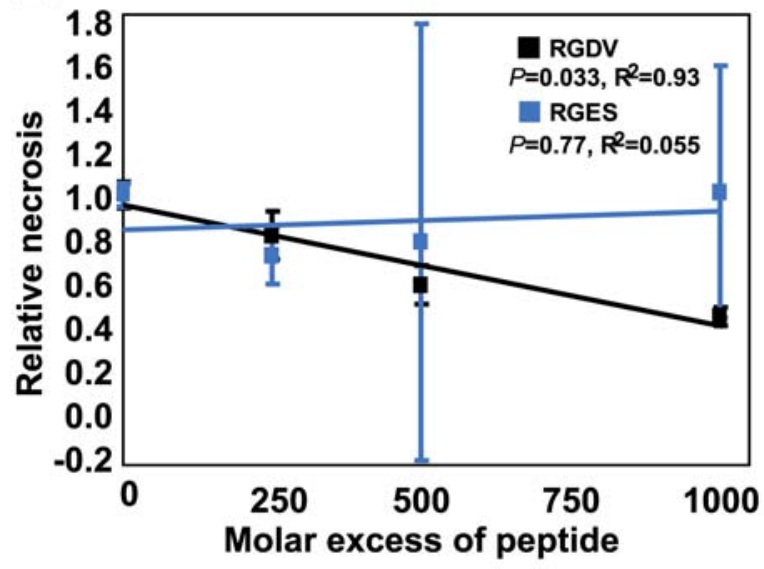

$\mathrm{D}$
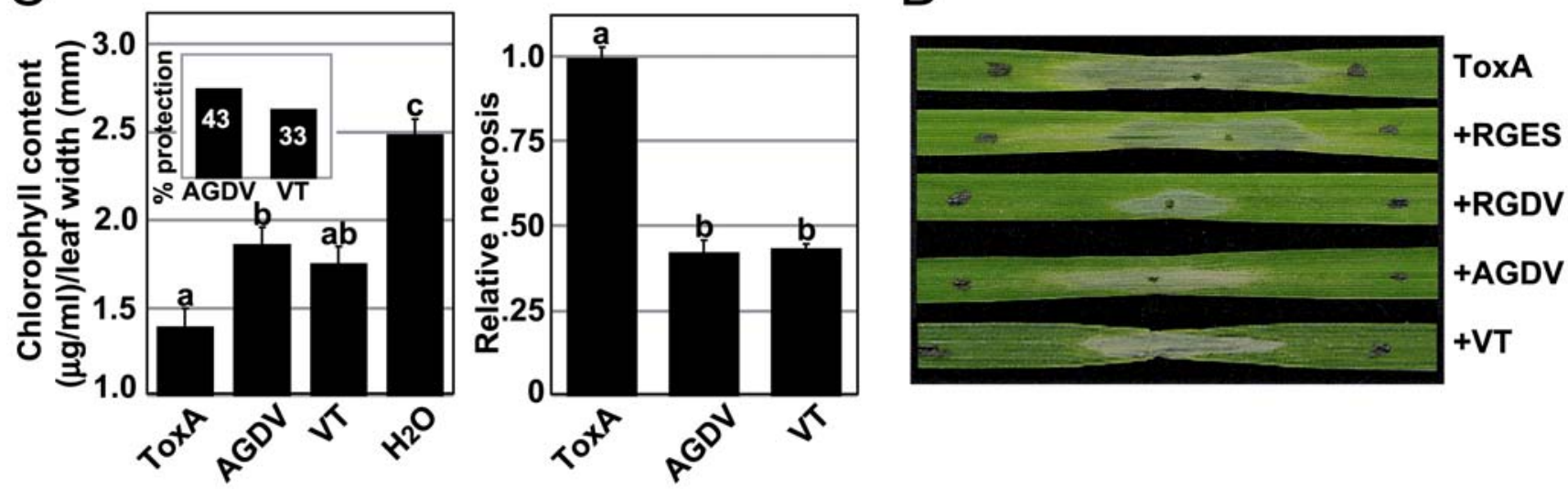

$\mathrm{F}$

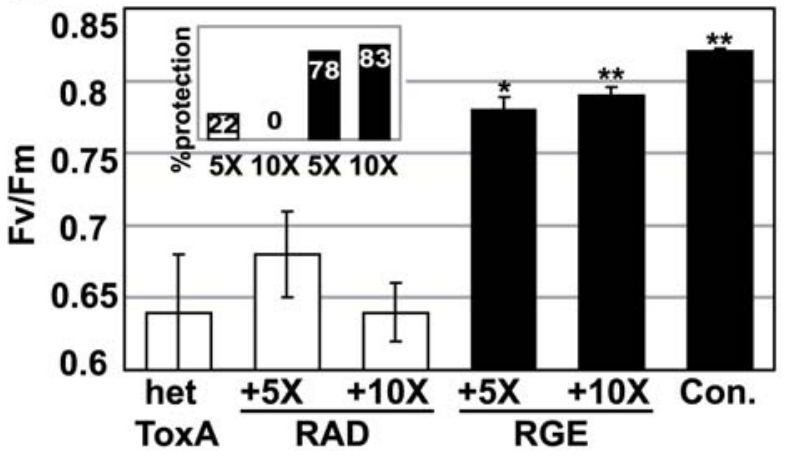

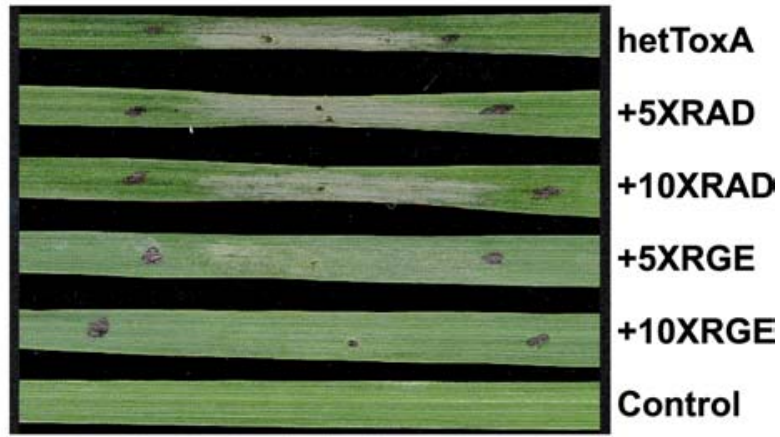

Fig. 4. Inhibition of ToxA activity by sequence-specific peptides and mutant fusion proteins. A, Dose dependent inhibition of ToxA activity, as determined by total chlorophyll. Leaves were infiltrated with 250-, 500-, or 1,000-fold molar excess of peptides and $1 \mu \mathrm{M}$ ToxA, ToxA alone, or $\mathrm{H}_{2} \mathrm{O}$ alone. The inset shows the percent $(\%)$ protection peptides provide against ToxA-induced chlorophyll reduction. Means of relative chlorophyll content of the RGDV or RGES peptide treatments were plotted against peptide concentration and were fit to a linear model. Error bars represent standard errors. B, Dose-dependent inhibition of ToxA activity, as determined by extent of necrosis. Leaves were treated as in A. Means of relative necrosis were plotted against peptide concentration and were fit to a linear model. Error bars represent standard errors. C, Inhibition of ToxA activity by additional sequence-specific peptides. Infiltration was performed with 1,000-fold molar excess of peptide to ToxA. Left panel, effect of different treatments on chlorophyll content. Means followed by the same letter are not significantly different as determined by Tukey's honestly significant difference (HSD) at $P<0.05$. The inset shows the percent $(\%)$ protection peptides provide against ToxA-induced chlorophyll reduction. Right panel, effect of different treatments on relative necrosis. Means followed by the same letter are not significantly different as determined by Tukey's HSD at $P<0.01$. Error bars represent standard errors. D, Leaf necrosis bioassay at day 2 after infiltration of leaves with 1,000-fold molar excess of peptides and $1 \mu \mathrm{M}$ ToxA or with ToxA alone. E, Chlorophyll fluorescence of ToxA alone or of ToxA and mutant protein coinfiltrated leaves. Leaves were infiltrated with $1 \mu \mathrm{M}$ hetToxA or coinfiltrated with either a 5- or 10-fold molar excess of mutant proteins and $1 \mu \mathrm{M}$ hetToxA. RAD $=$ g141a, RGE $=\mathrm{d} 142 \mathrm{e}, \mathrm{Con} .=$ untreated leaves. The inset shows the percent $(\%)$ protection by mutant proteins. A single asterisk $(*)$ represents a statistically significant difference between ToxA and the treatment $(P=0.05)$, and two asterisks $(* *)$ represents a statistically significant difference between ToxA and the treatment $(P=0.01)$. F, Leaf necrosis bioassay $(24 \mathrm{~h}$ postinfiltration $)$ of leaves infiltrated with $1 \mu \mathrm{M}$ hetToxA, coinfiltrated with either a 5- or 10-fold molar excess of mutant proteins and $1 \mu \mathrm{M}$ hetToxA, or control (untreated). 
proteins $\mathrm{N}$ and $\mathrm{C}$ terminal to the vitronectin-like motif, appear to be completely inactive (Fig. $3 \mathrm{H}$ and I).

\section{Competition of Ptr ToxA activity.}

Competition for integrin receptor binding occurs between vitronectin and RGD-containing peptides (Cherny et al. 1993), implicating the importance of the RGD amino acids of vitronectin (Arnaout et al. 2002; Ruoslahti and Pierschbacher 1986; Schvartz et al. 1999) in the interaction with one or more receptors. If the vitronectin-like motif of ToxA (Fig. 1) is important for interaction with another protein, small peptides with identity to amino acid residues within this motif could reduce toxin activity in a similar manner. An RGDV peptide was coinfiltrated at a 250-, 500-, and 1,000-fold molar excess to ToxA. Coinfiltration of the RGDV peptide with ToxA results in a dose-dependent decrease in toxin activity. Linear regression analysis indicates a statistically significant effect of RGDV peptide on chlorophyll content $(P=0.0098)$ (Fig. 4A). Percent protection from toxin activity is $5 \%$ for a 250 -fold molar excess of RGDV peptide, increases to $24 \%$ for a 500 fold molar excess, and is $56 \%$ for a 1,000-fold molar excess of peptide to ToxA (Fig. 4A inset). Coinfiltration of the control peptide (RGES) with ToxA appears to render some protection $(P=0.054)$, although the effect is less significant when compared with coinfiltration with the RGDV peptide (Fig. 4A). Results of an analysis of variance (ANOVA) indicate that coinfiltrations with ToxA and the RGES peptide did not differ significantly from infiltration with ToxA alone $(P=0.25)$, whereas coinfiltrations with the RGDV peptide were significantly different from infiltration with ToxA alone $(P<0.0001)$. Additionally, linear regression analysis of relative necrosis versus an increasing amount of peptide coinfiltrated with ToxA indicates that cotreatment with the RGDV peptide results in a dosedependent decrease in relative necrosis $(P=0.033)$, whereas cotreatment with the RGES peptide does not show a significant difference $(P=0.77)$ (Fig. 4B). Figure 4D shows a subset of leaves used to determine relative necrosis and demonstrates how the RGDV but not the RGES peptide prevents the spread of ToxA-induced necrosis.

Other peptides were tested at 1,000-fold molar excess to ToxA for an effect on toxin activity. The AGDV peptide contains three of the amino acid residues (GDV) present in the vitronectin-like motif of ToxA, whereas VT contains the entire motif (TVTRGDVYEL) (Fig. 1B). Both the AGDV and VT peptides were able to reduce toxin activity, as determined by the chlorophyll assay (Fig. 4C, left panel), and to provide 43 and $33 \%$ protection, respectively (Fig. $4 \mathrm{C}$ inset), though only coinfiltration with the AGDV peptide shows a statistically significant difference from toxin treatment alone. However, comparison of relative necrosis shows that both AGDV and VT coinfiltrations with ToxA lead to a significant decrease in necrosis compared with ToxA infiltration alone (Fig. 4C, right panel). The reduction of necrosis by coinfiltration of the AGDV or VT peptides can be seen in Figure 4D. Therefore, as RGD-containing peptides RGDV and VT are able to reduce ToxA activity, so are peptides that contain other amino acids (GDV) within the vitronectin-like domain (Fig.4).

Site-directed mutagenesis and peptide competition data suggest that more than the three amino acids of the RGD cell attachment motif are necessary for ToxA activity. To further evaluate this possibility, fusion proteins altered at one of the amino acids in the RGD cell attachment motif were used in competition experiments with hetToxA. If an intact RGD alone is sufficient for ToxA activity, then a fusion protein with a mutation in one of these amino acids should be unable to reduce activity of ToxA. In order to test this, an additional protein was constructed with the aspartic acid residue (D) of the
RGD motif substituted with a glutamic acid residue (E). The purpose of this mutation was twofold. First, the d142a mutant protein degraded rapidly after purification; therefore, this new protein (d142e) would allow us to test the importance of residue 142. Second, this protein better resembles the control RGES peptide used in competition experiments (Fig. 4A, B, and D) in which the aspartic acid residue (D) of the peptide is substituted with a glutamic acid residue (E). Infiltration with $\mathrm{d} 142 \mathrm{e}$ mutant protein at concentrations of hetToxA that induce necrosis elicits no necrosis (data not shown).

In protein competition studies, a chlorophyll fluorometer was used to detect early changes in leaves treated with hetToxA and leaves coinfiltrated with hetToxA and one of two RGD mutants, g141a (RAD) or d142e (RGE). Leaves treated with hetToxA have decreased chlorophyll fluorescence compared with control leaves (Fig. 4E). Leaves that were coinfiltrated with hetToxA plus a five- or tenfold molar excess of the d142e (RGE) mutant have a level of chlorophyll fluorescence greater than that of toxin alone and approaching that of control leaves (Fig. 4E). These treatments show a protection of 78 and $83 \%$, respectively (Fig. 4E, inset), and the level of leaf necrosis (Fig. $4 \mathrm{~F}$ ) is reflected in the values of the chlorophyll fluorometer assay (Fig. 4E). Interestingly, coinfiltration of the g141a (RAD) mutation with hetToxA did not result in protection (Fig. 4E and F).

\section{DISCUSSION}

Site-directed mutagenesis is a useful technique for determining the contribution of individual amino acids toward the function of a protein. Alanine is often the substituting amino acid of choice, as it confers no charge or side group. These attributes can help to determine the contribution individual amino acid side chains might have to protein structure and function. This tool in combination with the identification of conserved motifs with the use of the PROSITE database (Sigrist et al. 2002) allowed us to determine which amino acids might contribute to the function of ToxA (Fig. 1). Mutant proteins were expressed in E. coli and purified to homogeneity (Fig. 2). All of the expressed proteins migrate on an sodium dodecyl sulfate-polyacrylamide gel electrophoresis (SDSPAGE) gel like the control protein (hetToxA), with the exception of e145a (Fig. 2B). Droll and associates (2000) have shown that substitution of charged residues with alanine in the NS2BNS3 protease of the yellow fever virus also resulted in altered mobility of mutant proteins as compared with wild type. Additionally, the ToxA d142a mutant protein was prone to degradation and was, therefore, not included in this study. Alanine substitution of an aspartic acid residue of another protein, the pyrollidone carboxyl peptidase of Pseudomonas fluorescens, also resulted in an unstable protein (Le Saux et al. 1996).

Amino acids 62 and 93 of ToxA are glycines in the context of a consensus sequence for potential myristoylation sites (Towler and Gordon 1988) (Fig. 1A). Myristoylation usually occurs cotranslationally (Wilcox et al. 1987) on an N-terminal glycine residue (Towler et al. 1987). However, there has been a report of post-translational myristoylation following caspase 8 cleavage of a pro-protein that results in targeting of the newly cleaved protein to the mitochondria of mammalian cells undergoing apoptosis (Zha et al. 2000). Mature ToxA as secreted by the fungus has an N-terminal pyroglutamate residue (Tuori et al. 2000) and, therefore, is not myristoylated in the fungus. Additionally, there is no evidence to date that mature ToxA is cleaved in planta. Therefore, these motifs were not included in this study.

Protein phosphorylation is a major post-translational modification that regulates protein activity (Clark et al. 2001). The bacterial heterologous expression system used in this study 
does not generate eukaryotic post-translational modifications; therefore, none of the proteins produced in this study are likely phosphorylated during expression. Also, mass spectroscopy data of ToxA isolated from culture filtrate of a ToxA-producing isolate show that phosphorylation does not occur in the fungus (Tuori et al. 1995). Nevertheless, it is possible that ToxA is phosphorylated by plant kinases in planta. As of June 2003, the PlantsP database (Gribskov et al. 2001) has compiled a list of $>1,003$ unique kinase sequences from the rice genome and 1,019 from the Arabidopsis thaliana genome. None of these kinase sequences are homologous to PKC, an important signal transducer found in animal systems (Sanders et al. 2002; Satterlee and Sussman 1998; Wang et al. 2003). Chandok and Sopory (1998) have purified a protein from maize that has similar characteristics to $\mathrm{PKC}$, but no plant protein substrates have been described, nor has the protein sequence been identified. It is, therefore, still unknown if plants produce PKC. ToxA proteins with mutant PKC motifs were active, and phosphorylation at those sites does not appear necessary for activity (Fig. 3A through C). The lack of a PKC homolog in plants may account for our findings that mutagenesis of potential PKC sites appears to have little effect on toxin activity.

We show, however, that mutagenesis of two putative CK2 phosphorylation sites, $\mathrm{t} 132$ and $\mathrm{t} 139$, does alter ToxA activity (Fig. 3D through F), suggesting that these amino acids may be phosphorylated in planta. These sites are located in or near the vitronectin-like motif present in ToxA (Fig. 1). Vitronectin, an animal protein present in the extracellular matrix, is necessary for many biological functions and binds receptors through an RGD cell attachment motif (Schvartz et al. 1999). Interestingly, a CK2 has been shown to phosphorylate vitronectin near its RGD-containing motif. This phosphorylation regulates binding to at least one of vitronectin's integrin receptors (Seger et al. 1998). In plants, CK2 genes have been implicated in light-regulated gene expression (Lee et al. 1999), salicylic acid-induced transcriptional activation (Hidalgo et al. 2001), and regulation of circadian rhythms (Sugano et al. 1999). Recently, the gene encoding the alpha subunit of a wheat $C K 2$ gene has been cloned and localized to wheat chromosome $5 \mathrm{~A}$ (Kato et al. 2002). The area that the $C K 2$ gene maps to on the $5 \mathrm{~A}$ chromosome contains markers that indicate it may be orthologous to the region of the $5 \mathrm{~B}$ chromosome that harbors the Tsn1 locus (Faris et al. 2000; Kato et al. 2002). Because we have shown that mutagenesis of CK2 motifs of ToxA reduces activity (Fig. 3D through F), it will be interesting to determine if ToxA is a substrate for wheat CK2 and if the Tsn1 locus encodes a $C K 2$-like gene.

Threonine 167 (t167) could potentially be phosphorylated by either a PKC-like kinase or a CK2-like kinase; however, the t167a mutant protein is as active as the control toxin (Fig. 3D through F). This indicates that phosphorylation of t167 is not important for activity, which is not surprising, since truncation mutants that no longer contain this amino acid are also fully active (V. A. Manning and L. M. Ciuffetti, unpublished data).

The RGD motif of vitronectin has been shown to be important for its interaction with all of its integrin receptors (Cherny et al. 1993; Schvartz et al. 1999). Previous studies have shown that g141a and d142e mutations in the RGD motif of ToxA can lead to decreased toxin activity (Meinhardt et al. 2002). These studies, however, used crude extracts, and therefore, the concentrations of mutant proteins were not determined. The current study confirmed the findings of Meinhardt and associates (2002) that amino acids g141 and d142 within the RGD cell attachment motif are important for ToxA activity (Figs. 3G through $\mathrm{I}$ and $4 \mathrm{E}$ and $\mathrm{F}$ ) and expanded the list of amino acids that are necessary for activity to include those residues sur- rounding the RGD cell attachment motif corresponding to a vitronectin-like region (Fig. 3G through I). One exception to this finding is the valine to alanine substitution at amino acid 138 within the vitronectin-like motif that had no effect on toxin activity. It is possible that this valine is not a critical residue within the vitronectin-like domain, and therefore, the conservative valine to alanine substitution would be less likely to have an effect on protein structure and function.

The plant cell wall-plasma membrane continuum has been compared with the animal extracellular matrix-plasma membrane continuum in that the connection between the two components is required for environmental perception and cell communication (Brownlee 2002; Reuzeau and Pont-Lezica 1995). In animal systems, the interaction between vitronectin, located in the extracellular matrix, and one or more integrin receptors, located on plasma membranes, has been well characterized. Integrin receptor binding leads to intracellular signaling that results in protein phosphorylation, cytoskeletal rearrangements, and changes in gene expression (Boudreau and Jones 1999). Both vitronectin- and integrin-like proteins have been described in plants (Faik et al. 1998; Kiba et al. 1998; Laboure et al. 1999; Nagpal and Quatrano 1999; Sanders et al. 1991; Schindler et al. 1989; Sun et al. 2000; Swatzell et al. 1999). One vitronectin-like protein that has been cloned from plants was shown to be similar to translational elongation factor- $1 \alpha$ and localizes to the cell wall (Zhu et al. 1994). Nagpal and Quatrano (1999) have cloned an integrin-like gene from Arabidopsis whose product localizes to the plasma membrane and the cytoplasm. It is possible that ToxA, via its vitronectinlike motif, may disrupt the cell wall-plasma membrane continuum by interfering with a vitronectin-like protein binding to its plasma membrane integrin-like receptor. If this were the case, one might expect that treatment with RGD-containing peptides alone would elicit a similar response to ToxA treatment. This does not occur, as RGD peptide treatment alone does not result in tissue necrosis (data not shown). Similarly, infiltration of the VT peptide that contains the RGD tri-peptide sequence as well as additional amino acids that make up the vitronectin-like domain in ToxA (Fig. 1) does not result in tissue necrosis (data not shown). Therefore, it is likely more than a disruption of the plasma membrane-cell wall continuum is necessary for ToxA activity.

Treatment with RGD peptides in various plant systems reduced attachments of the plasma membrane to the cell wall (Canut et al. 1998; Faik et al. 1998; Mellersh and Heath 2001; Schindler et al. 1989). Additionally, RGD peptide treatment led to a decrease in plant defense responses (Kiba et al. 1998; Mellersh and Heath 2001). For example, RGD but not RGE peptide treatment resulted in a decrease in the accumulation of phytoalexin in pea in response to an elicitor from Mycosphaerella pinodes (Kiba et al. 1998). Mellersh and Heath (2001) demonstrated that both host and nonhost plant defense responses to the biotrophic fungus Uromyces vignae are decreased by RGD peptide treatment. Furthermore, they established that this was likely due to the loss of communication between the cell wall and the plasma membrane, through the reduction of Hechtian strands. Therefore, a role of the RGD-containing motif of ToxA may be in the inhibition of early plant defense responses by dissociating the cell wall from the plasma membrane. However, this must be accompanied by an additional activity of ToxA, because necrosis occurs with ToxA treatment but not with RGD-containing peptides.

Meinhardt and associates (2002) reported that a 2,000-fold excess of peptides containing RGD but not RGE transiently protected plants from ToxA-induced electrolyte leakage at $4 \mathrm{~h}$ postinfiltration. However, leaf necrosis bioassays were not performed to determine the long-term effects of peptide coinfil- 
tration on necrosis induced by ToxA. Our laboratory had difficulty establishing a reproducible electrolyte leakage assay that accurately reflected the extent of necrosis and protection from necrosis seen in leaves infiltrated with different concentrations of ToxA or coinfiltrated with ToxA and peptide, respectively (data not shown). A total chlorophyll assay and a leaf necrosis bioassay were therefore used to measure the extent of necrosis. The chlorophyll assay was highly reproducible and was confirmed by the results of a leaf necrosis bioassay (Figs. 3 and 4). Interestingly and in contrast to Meinhardt and associates (2002), who describe RGD peptide inhibition of ToxA as transient, in the current study, inhibition is observed 2 days postinfiltration (Fig. 4A, B, and D). Additionally, the control peptide (RGES) provides some protection, although this protection is not statistically significant (Fig. 4A, B, and D). The difference in the data presented here and that presented by Meinhardt and associates (2002) may be explained by a lack of correlation between electrolyte leakage and necrosis, as was shown for Periconia toxin. Evaluation of the effects of the HST from Periconia circinata showed that electrolyte leakage can be dissociated from symptom development (Dunkle and Wolpert 1981). Because electrolyte leakage occurs early in the plant's response to ToxA (Kwon et al. 1996), whereas loss of chlorophyll and visible necrosis occur at a later time, it is likely that the study of Meinhardt and associates (2002) and the current study are measuring two different physiological processes. Another possibility for the discrepancy between the two studies is the difference in the peptides we chose for inhibition studies. The RGD-containing peptide used in this study contained an additional valine at the carboxy terminus (RGDV) that corresponds to the valine present in ToxA, whereas Meinhardt and associates (2002) used a peptide that contained only RGD.

Because RGD peptide treatment has been shown to decrease host defense responses via dissociation of the cell wall from the cell membrane (Mellersh and Heath 2001), it is possible that the decrease in necrosis observed with coinfiltration of ToxA with peptides is not directly due to competition of ToxA with RGD peptides for an interacting protein, but instead, is a result of the disruption of the cell wall-plasma membrane continuum as suggested by Meinhardt and associates (2002). In this scenario, an intact plasma membrane-cell wall interaction would be required for ToxA activity. We show, however, that we can substitute the arginine (R) of the RGDV peptide with an alanine (maintaining the GDV of ToxA) and still get protection (Fig. 4C and D). Similarly, the VT peptide encoding the ToxA vitronectin-like motif confers protection (Fig. 4C and D). Therefore, the inhibition of necrosis appears to be specific to the ToxA molecule and not due to the disruption of the cell wall-plasma membrane continuum by the RGD peptide. Given these data and the finding that mutagenesis of these amino acids results in loss of function, it is likely that competition with one or more interacting proteins is a plausible explanation.

The loss of ToxA activity due to mutations that are within the vitronectin-like motif but outside of the RGD cell attachment motif (Fig. 3G through I) in combination with the inhibition of ToxA activity with peptides that include but are not limited to the RGD motif of ToxA (Fig. 4A through D) suggests that more than just the RGD cell attachment motif is necessary for ToxA activity. Additionally, results of mutant protein competition experiments (Fig. 4E and F) provide further evidence that more than the RGD is necessary for ToxA activity. Redick and associates (2000) used a similar approach of site-directed mutant protein competition to show an adhesion synergy site in the RGDcontaining protein fibronectin. Chlorophyll fluorescence was used to monitor early plant responses to toxin, because it is more sensitive than the total chlorophyll assay at detecting early symptom development in response to ToxA infiltration (data not shown). Chlorophyll fluorescence has been used to evaluate leaf senescence (He et al. 2002), the induction of the hypersensitive response (Allen et al. 1999), and fungal-mediated reduction of photosynthesis (Manter 2002). A decrease in chlorophyll fluorescence in response to ToxA treatment is evident within $24 \mathrm{~h}$ (Fig. 4E). Furthermore, the d142e (RGE) mutant protein is capable of competing with hetToxA to prevent necrosis (Fig. 4E and F). If necrosis induction occurred solely via the ToxA RGD motif, we would not expect the d142e mutant toxin protein to compete with hetToxA; in other words, hetToxA should have full activity in the presence of the d142e fusion protein. The fact that the d142e mutant does protect against ToxA indicates that competition solely through the RGD motif does not occur and that more than the RGD motif is necessary for complete toxin activity.

The lack of competition by the g141a (RAD) mutant protein was surprising (Fig. 4E and F). One possible explanation is that an alanine in the place of a glycine within this context leads to a protein that is unstable in planta. Although this protein appears to be stable in vitro, conditions in the apoplastic space or cell interior may lead to protein degradation, as was shown with the 17D envelope protein of the yellow fever virus. In the latter case, mutation of the RGD motif (located on a solvent-exposed loop) to RAD led to an unstable protein and affected the ability of the virus to spread to neighboring cells (van der Most et al. 1999).

In summary, we have found that multiple motifs, specifically two CK2-like phosphorylation motifs and a vitronectinlike motif, likely play a role in ToxA activity. If phosphorylation is necessary, it must occur in planta, because the proteins that were produced in this study were not post-translationally modified (Tuori et al. 2000) nor is ToxA phosphorylated in the fungus (Tuori et al. 1995). Several lines of evidence suggest that ToxA enters cells of sensitive wheat tissue. In a yeast twohybrid screen of proteins from sensitive wheat, ToxA interacts with a protein that contains a putative chloroplast localization signal (V. A. Manning and L. M. Ciuffetti, unpublished data). In addition, a heterologously expressed GFP-ToxA fusion protein localizes to the chloroplasts of sensitive tissue (V. A. Manning and L. M. Ciuffetti, unpublished data). These data suggest the chloroplast as the site of action of ToxA and that ToxA crosses the plasma membrane to gain access to the chloroplast. Additionally, Kwon and associates (1998) have shown that vanadate, an $\mathrm{H}^{+}$ATPase inhibitor, prevents ToxAinduced electrolyte leakage and speculate that $\mathrm{H}^{+}$ATPases may be necessary for import of ToxA into the cell. While the vitronectin-like motif may be important for recognition at the plasma membrane, it is also possible that this motif is important in other protein-protein interactions within sensitive cells. We are in the process of determining if mutations in the vitronectin-like motif prevent toxin entry into the cell or the chloroplast. Additionally, data from X-ray crystallographic analysis of ToxA, currently ongoing in collaboration with P. A. Karplus (Department of Biochemistry and Biophysics, Oregon State University, Corvallis, OR, U.S.A.), will be helpful to determine if the RGD motif of ToxA is in a solvent-exposed loop, as is common in proteins that contain RGD motifs and bind to integrin receptors (Ely et al. 1995). Crystal structure will likely also provide information on any additional motifs that may be important for ToxA function and localization.

\section{MATERIALS AND METHODS}

\section{Plant growth and leaf necrosis bioassays.}

Plants were grown in $16 \mathrm{~h}$ of light at $23^{\circ} \mathrm{C}$ and $8 \mathrm{~h}$ of dark at $19^{\circ} \mathrm{C}$ for two to three weeks. All leaf infiltrations were performed on the secondary leaves of the susceptible wheat culti- 
var Katepwa, with a modified-Hagborg device (Hagborg 1970). For leaf necrosis bioassays, three leaves were infiltrated for each treatment, and plants were returned to the growth chamber and were incubated under the above conditions. Leaves were harvested at either day 2 or day 5 postinfiltration, and the extent of necrosis was documented via digital scanning.

\section{Site-directed mutagenesis.}

The sequence for one primer of each reverse-complement primer pair required for mutagenesis is shown in Table 1 . Sitedirected mutagenesis was performed on pCT68 (Tuori et al. 2000), using the QuikChange site-directed mutagenesis kit (Stratagene, La Jolla, CA, U.S.A.), following manufacturer's recommendations. The PCR reaction included $1 \times P f u$ turbo DNA polymerase buffer, (50 ng of template, $125 \mathrm{ng}$ of each primer, $0.2 \mathrm{mM} \mathrm{dNTPs}$, and $2.5 \mathrm{U}$ of $P f u$ turbo DNA polymerase. The cycles were as follows: 1 cycle at $95^{\circ} \mathrm{C}$ for $1 \mathrm{~min}$ and 18 cycles at $95^{\circ} \mathrm{C}$ for $30 \mathrm{~s}, 55^{\circ} \mathrm{C}$ for $1 \mathrm{~min}, 68^{\circ} \mathrm{C}$ for 10 $\min (2 \mathrm{~min} / \mathrm{kb})$. After completion of the PCR reaction, $10 \mathrm{U}$ of $D p n I$ were added directly to the reaction, which was further incubated for $1 \mathrm{~h}$ at $37^{\circ} \mathrm{C}$. The mix was directly transformed into XL1-Blue cells (Stratagene) according to manufacturer's instructions. Plasmids from two to four colonies were sequenced to confirm the appropriate mutation at the Central Services Laboratory, Center for Gene Research and Biotechnology, Oregon State University. Plasmids containing the mutations of interest were transformed into Origami cells (Novagen, Madison, WI, U.S.A.) for expression of mutagenized proteins.

\section{Expression and purification of fusion proteins and toxin.}

ToxA was produced as described by Touri and associates (1995). Fusion proteins were produced as previously described (Tuori et al. 2000) with some modifications. Luria-Bertani medium was inoculated at a 1:100 dilution from an overnight culture, was allowed to grow for $1 \mathrm{~h}$, and then, was induced for $4 \mathrm{~h}$ with $1 \mathrm{mM}$ isopropyl-beta-D-thiogalactopyranoside. Cells were harvested and lysed with BugBuster (Novagen), and nucleic acids were digested with $1 \mu$ Benzonase (Novagen) per $\mathrm{ml}$ of lysis buffer. Inclusion bodies were harvested, washed, and resuspended in $8 \mathrm{M}$ guanidine $\mathrm{HCl}, 10$ mM DTT. This solution was then dialyzed against decreasing concentrations of urea $(6,4,2$, and $0 \mathrm{M})$ in refolding buffer $(250 \mathrm{mM} \mathrm{NaCl}, 100 \mathrm{mM}$ sodium phosphate buffer, $10 \mathrm{mM}$ Tris base, $4 \%$ glycerol, $1 \mathrm{mM}$ EDTA, $0.005 \%$ Tween-20, pH 8.0) plus $10 \mathrm{mM}$ ethylene diamine, (Sigma, St. Louis). Proteins were dialyzed to Ni-buffer $(250 \mathrm{mM} \mathrm{NaCl}, 100 \mathrm{mM}$ sodium phosphate buffer, and $4 \%$ glycerol, $\mathrm{pH} 8.0$ ), and then, were adsorbed to Ni-NTA agarose (Qiagen USA, Valencia, CA, U.S.A.), and were washed (1× Ni-buffer, $20 \mathrm{mM}$ imidazole, $0.5 \%$ Tween-20) and eluted with $500 \mathrm{mM}$ imidazole in Ni-buffer. Prior to infiltration, proteins were dialyzed to water.

\section{Quantitation and gel electrophoresis of fusion proteins.}

Protein concentration was determined with the Bio-Rad DC protein assay kit (Bio-Rad, Hercules, CA, U.S.A.), according to manufacturer's instructions. RNase A was used as the standard. SDS-PAGE was performed according to Fling and Gregerson (1986). Gels were stained with GelCode Blue (Pierce, Rockford, IL, U.S.A.), as suggested by the manufacturer.

\section{Total chlorophyll assay and relative necrosis determination.}

For each assay, 3-cm sections of secondary leaves were infiltrated as described above for the leaf necrosis bioassay. After 48 $\mathrm{h}, 2.5-\mathrm{cm}$ segments were excised from the inside of the infiltration zone, and the width was measured and approximated to the nearest $0.25 \mathrm{~mm}$. Single leaf sections were placed into vials containing $3 \mathrm{ml}$ of $95 \%$ ethanol to extract chlorophylls. Vials were incubated overnight at room temperature in the dark. Absorbance readings were taken at $654 \mathrm{~nm}$ on $1 \mathrm{ml}$ of chlorophyll extract, using a Beckman DU640 spectrophotometer. Total chlorophyll was calculated using the formula chlorophyll total $(\mu \mathrm{g} / \mathrm{ml})=25.7 \times($ Absorbance at $654 \mathrm{~nm})$. This value was then divided by leaf width. Each mutant protein was assayed for activity three separate times (Fig. 3). Each time the assay was performed in triplicate, i.e., three different leaves were infiltrated and evaluated for chlorophyll content. Not all proteins were tested on the same day. All statistical analyses were performed using Statgraphics (StatPoint, Englewood Cliffs, NJ, U.S.A.). To determine if the three sets of triplicates could be combined for further analysis, the variances of all of the triplicates were compared using a Bartlett's test. Results of the Bartlett's test indicate that none of the variances were significantly different from each other $(P>0.05)$. Therefore, all of the values obtained for a fusion protein (nine total) were combined for further statistical analyses. ANOVA showed statistically significant differences among the chlorophyll contents of the leaves treated with different mutant proteins $(P<0.0001)$.

Peptides (RGES, RGDV, and AGDV) were purchased from American Peptide Company (Sunnyvale, CA, U.S.A.) or synthesized by Bio-Synthesis (Lewisville, TX, U.S.A.) (VT = vitronectin-like motif of ToxA, amino acids 136 through 147 [Fig. 1B]). When testing whether a peptide could inhibit ToxA activity in a dose-dependent manner (Fig. 4A), each experiment included infiltration of ToxA-alone and $\mathrm{H}_{2} \mathrm{O}$-alone controls and coinfiltration of three increasing amounts of one of the peptides (RGDV or RGES) and ToxA performed in triplicate. Each experiment was repeated on three different days. To determine if the three sets of triplicates could be combined for further analysis, the variances of all of the triplicates were compared using a Bartlett's test. Results of the Bartlett's test indicate that none of the variances of the triplicates for the RGDV or RGES experiments were significantly different $(P=$ 0.38 and 0.19 respectively); therefore, all data points for each peptide were combined for further analysis. To compare the RGDV and RGES peptide dose responses, relative chlorophyll was calculated to normalize the peptide coinfiltrations to ToxA controls and to eliminate any differences that may have been introduced by performing the assays on different days. Relative chlorophyll was calculated by dividing individual values by the mean of all of the ToxA values. For RGDV and RGES peptide dose-response experiments, means of all values were used for linear regression analysis.

To test the ability of other peptides to inhibit ToxA activity, the AGDV and VT peptides were coinfiltrated at 1,000-fold molar excess to ToxA. Each experiment included an $\mathrm{H}_{2} \mathrm{O}$-and ToxA-alone control. Each experiment was performed in triplicate on four different days. Variances of the individual triplicates were tested as described above, to determine if the individual experiments could be combined. Results of the Bartlett's test indicated there were no differences in the variances of the treatments $(P=0.83)$. Results of an ANOVA indicated a statistically significant difference in the peptide cotreatments and ToxA alone at a $P=0.0085$. For peptide inhibition studies, percent $(\%)$ protection was calculated as by Meinhardt and associates (2002), $\left[1-\left(\mathrm{C}_{\text {toxin }}+\right.\right.$ peptide $\left.\left.-\mathrm{C}_{\text {peptide }}\right) /\left(\mathrm{C}_{\text {toxin }}-\mathrm{C}_{\text {water }}\right)\right] \times$ 100 , where $\mathrm{C}=$ conductivity, with certain modifications. In our calculations, the means of treatments were used in the equation $\left[1-\left(\mathrm{C}_{\text {toxin }}+\right.\right.$ peptide $\left.\left.-\mathrm{C}_{\text {water }}\right) /\left(\mathrm{C}_{\text {toxin }}-\mathrm{C}_{\text {water }}\right)\right] \times 100$, where $\mathrm{C}=$ total chlorophyll and $\mathrm{C}_{\text {water }}$ was substituted for $\mathrm{C}_{\text {peptide }}$, because there was no difference in the chlorophyll content of waterand peptide-treated leaves (data not shown).

To compare the RGDV and RGES peptide dose responses, relative necrosis was calculated to normalize the peptide coin- 
filtrations to ToxA controls and to eliminate any differences that may have been introduced by performing the assays on different days. The length of the necrotic area was measured to the nearest millimeter. Relative necrosis was calculated by dividing the individual values of necrotic region lengths by the mean of the size of all of the ToxA necrotic region lengths. For RGDV and RGES peptide dose-response experiments, means of all values were used for linear regression analysis. Results of a Bartlett's test indicated there were statistically significant differences in the variances of the individual treatments (RGDV, $P=0.03$ and RGES, $P=0.04$ ); therefore, an ANOVA was not performed.

\section{Chlorophyll fluorometer assay.}

An OS1-FL fluorometer (Opti-Sciences, Tyngsboro, MA, U.S.A.) was used to measure chlorophyll fluorescence. Leaves were infiltrated with ToxA fusion protein or coinfiltrated with premixed mutant competitor fusion protein and ToxA fusion protein. After treatment $(24 \mathrm{~h})$, leaves were dark-adapted for 5 min with dark adaptation clips, and then, $\mathrm{Fv} / \mathrm{Fm}$ readings were taken according to manufacturer's instructions. Fv/Fm is the ratio of variable fluorescence to maximal fluorescence. The experiment was repeated on three different days and was conducted in triplicate on each day. All values (nine for each treatment) were combined to generate means and standard errors. A Bartlett's test indicated there were significant differences in the variances of the treatments; therefore two-tailed $t$-tests, at the 95 and $99 \%$ confidence level, were used to determine significant differences between treatments. Percent protection was calculated on the means of the treatments using the equation $\left[1-\left(\mathrm{C}_{\text {toxin }}+\right.\right.$ mutant protein $\left.\left.-\mathrm{C}_{\text {control }}\right) /\left(\mathrm{C}_{\text {toxin }}-\mathrm{C}_{\text {control }}\right)\right] \times 100$, where $\mathrm{C}=$ chlorophyll fluorescence and $\mathrm{C}_{\text {control }}$ is substituted for $\mathrm{C}_{\mathrm{water}}$, because there were no differences in the chlorophyll fluorescence of water and untreated (control) leaves.

\section{ACKNOWLEDGMENTS}

We would like to thank T. Wolpert for his thoughtful comments and review as well as P. Martinez and I. Pandelova for their insight and discussions. We would also like to thank D. Manter for the use of the chlorophyll fluorometer and C. Mundt, T. Manning, and K. Johnson for help with statistical analyses. This work was funded by the United States Department of Agriculture National Research Initiative (grant number 0135319-10017) and in part by the National Science Foundation (grant number 9600914).

\section{LITERATURE CITED}

Ali, S., Ling, H., Meinhardt, S. W., and Francl, L. J. 2002. A new race of Pyrenophora tritici-repentis that produces a putative host-selective toxin. (Abstr.) Phytopathology 92:S3.

Allen, L. J., MacGregor, K. B., Koop, R. S., Bruce, D. H., Karner, J., and Bown, A. W. 1999. The relationship between photosynthesis and a mastoparan-induced hypersensitive response in isolated mesophyll cells. Plant Physiol. 119:1233-1241.

Anderson, J. A., Effertz, R. J., Faris, J. D., Francl, L. J., Meinhardt, S. W., and Gill, B. S. 1999. Genetic analysis of sensitivity to a Pyrenophora tritici-repentis necrosis-inducing toxin in durum and common wheat. Phytopathology 89:293-297.

Arnaout, M. A., Goodman, S. L., and Xiong, J.-P. 2002. Coming to grips with integrin binding to ligands. Curr. Opin. Cell Biol. 14:641-651.

Ballance, G. M., Lamari, L., and Bernier, C. C. 1989. Purification and characterization of a host-selective necrosis toxin from Pyrenophora tritici-repentis. Physiol. Mol. Plant Pathol. 35:203-213.

Ballance, G. M., Lamari, L., Kowatsch, R., and Bernier, C. C. 1996. Cloning, expression and occurrence of the gene encoding the Ptr necrosis toxin from Pyrenophora tritici-repentis. Mol. Plant Pathol. 1996/1209ballance. Online publication.

Boudreau, N. J., and Jones, P. L. 1999. Extracellular matrix and integrin signaling: The shape of things to come. Biochem. J. 339:481-488.

Brownlee, C. 2002. Role of the extracellular matrix in cell-cell signaling: Paracrine paradigms. Curr. Opin. Plant Biol. 5:396-401.
Canut, H., Carrasco, A., Galaud, J. P., Cassan, C., Bouyssou, H., Vita, N. Ferrara, P., and Pont-Lezica, R. 1998. High affinity RGD-binding sites at the plasma membrane of Arabidopsis thaliana links the cell wall. Plant J. 16:63-71.

Chandok, M. R., and Sopory, S. K. 1998. ZmcPKC70, a protein kinase Ctype enzyme from maize. J. Biol. Chem. 273:19235-19242.

Cherny, R. C., Honan, M. A., and Thiagarajan, P. 1993. Site-directed mutagenesis of the arginine-glycine-aspartic acid in vitronectin abolishes cell adhesion. J. Biol. Chem. 268:9725-9729.

Ciuffetti, L. M., and Tuori, R. P. 1996. Analysis of the ToxA gene of Pyrenophora tritici-repentis, causal agent of tan spot of wheat. (Abstr.) Phytopathology 86:S91.

Ciuffetti, L. M., Tuori, R. P., and Gaventa, J. M. 1997. A single gene encodes a selective toxin causal to the development of tan spot of wheat. Plant Cell 9:135-144.

Ciuffetti, L. M., Francl, L. J., Ballance, G. M., Bockus, W. W., Lamari, L., Meinhardt, S. W., and Rasmussen, J. B. 1998. Standardization of toxin nomenclature in the Pyrenophora tritici-repentis/wheat interaction. Can. J. Plant Pathol. 20:421-424.

Clark, G. B., Thompson, G., and Roux, S. J. 2001. Signal transduction mechanisms in plants: An overview. Curr. Sci. 80:170-177.

Droll, D. A., Krishna Murthy, H. M., and Chambers, T. J. 2000. Yellow fever virus NS2B-NS3 protease: Charged-to-alanine mutagenesis and deletion analysis define regions important for protease complex formation and function. Virology 275:335-347.

Dunkle, L. D., and Wolpert, T. J. 1981. Independence of milo disease symptoms and electrolyte leakage induced by the host-specific toxin from Periconia circinata. Physiol. Plant Pathol. 18:315-323.

Effertz, R. J., Meinhardt, S. W., Anderson, J. A., Jordahl, J. G., and Francl, L. J. 2002. Identification of a chlorosis-inducing toxin from Pyrenophora tritici-repentis and the chromosomal location of an insensitivity locus in wheat. Phytopathology 92:527-533.

Ely, K. R., Kunicki, T. J., and Kodandapani, R. 1995. Common molecular scaffold for two unrelated RGD molecules. Protein Eng. 8:823-827.

Faik, A., Laboure, A. M., Gulino, D., Mandaron, P., and Falconet, D. 1998. A plant surface protein sharing structural properties with animal integrins. Eur. J. Biochem. 253:552-559.

Faris, J. D., Anderson, J. A., Francl, L. J., and Jordahl, J. G. 1996. Chromosomal location of a gene conditioning insensitivity in wheat to a necrosis-inducing culture filtrate from Pyrenophora tritici-repentis. Phytopathology 86:459-463.

Faris, J. D., Haen, K. M., and Gill, B. S. 2000. Saturation mapping of a gene-rich recombination hot spot region in wheat. Genetics 154:823835.

Fling, S. P., and Gregerson, D. S. 1986. Peptide and protein molecular weight determination by electrophoresis using a high-molarity tris buffer system without urea. Anal. Biochem. 155:83-88.

Flor, H. H. 1971. Current status of the gene-for-gene concept. Annu. Rev. Phytopathol. 9:275-296.

Friesen, T. L., Rasmussen, J. B., Kwon, C. Y., Ali, S., Francl, L. J., and Meinhardt, S. W. 2002. Reaction of Ptr ToxA-insensitive wheat mutants to Pyrenophora tritici-repentis race 1. Phytopathology 92:38-42.

Gamba, F. M., Lamari, L., and Brule-Babel, A. L. 1998. Inheritance of race-specific necrotic and chlorotic reactions induced by Pyrenophora tritici-repentis in hexaploid wheats. Can. J. Plant Pathol. 20:401-407.

Gribskov, M., Fana, F., Harper, J., Hope, D. A., Harmon, A. C., Smith, D. W., Tax, F. E., and Zhang, G. 2001. PlantsP: A functional genomics database for plant phosphorylation. Nucleic Acids Res. 29:111-113.

Hagborg, W. A. F. 1970. A device for injecting solutions and suspensions into thin leaves of plants. Can. J. Bot. 48:1135-1136.

He, Y., Fukushige, H., Hildebrand, D. F., and Gan, S. 2002. Evidence supporting a role of jasmonic acid in Arabidopsis leaf senescence. Plant Physiol. 128:876-884.

Hidalgo, P., Garreton, V., Berrios, C. G., Ojeda, H., Jordana, X., and Holuigue, L. 2001. A nuclear casein kinase 2 activity is involved in early events of transcriptional activation induced by salicylic acid in tobacco. Plant Physiol. 125:396-405.

Kato, K., Kidou, S., Miura, H., and Sawada, S. 2002. Molecular cloning of the wheat CK2alpha gene and detection of its linkage with Vrn-A1 on chromosome 5A. Theor. Appl. Genet. 104:1071-1077.

Kiba, A., Sugimoto, M., Toyoda, K., Ichinose, Y., Yamada, T., and Shiraishi, T. 1998. Interaction between cell wall and plasma membrane via RGD motif is implicated in plant defense responses. Plant Cell Physiol. 39:1245-1249.

Kwon, C. Y., Rasmussen, J. B., Francl, L. J., and Meinhardt, S. W. 1996. A quantitative bioassay for necrosis toxin from Pyrenophora tritici-repentis based on electrolyte leakage. Phytopathology 86:1360-1363.

Kwon, C. Y., Rasmussen, J. B., and Meinhardt, S. W. 1998. Activity of Ptr ToxA from Pyrenophora tritici-repentis requires host metabolism. Physiol. Mol. Plant Pathol. 52:201-212. 
Laboure, A. M., Faik, A., Mandaron, P., and Falconet, D. 1999. RGDdependent growth of maize calluses and immunodetection of an integrin-like protein. FEBS Lett. 442:123-128.

Lamari, L., and Bernier, C. C. 1989. Toxin of Pyrenophora tritici-repentis: Host-specificity, significance of disease, and inheritance of host reaction. Phytopathology 79:740-744.

Lamari, L., and Bernier, C. C. 1991. Genetics of tan necrosis and extensive chlorosis in tan spot of wheat caused by Pyrenophora tritici-repentis. Phytopathology 81:1092-1095.

Lamari, L., Strelkov, S. E., Yahyaoui, A., Orabi, J., and Smith, R. B. 2003. The identification of two new races of Pyrenophora tritici-repentis from the host center of diversity confirms a one-to-one relationship in tan spot of wheat. Phytopathology 93:391-396.

Le Saux, O., Gonzales, T., and Robert-Baudouy, J. 1996. Mutationa analysis of the active site of Pseudomonas fluorescens pyrrolidone carboxyl peptidase. J. Bacteriol. 178:3308-3313.

Lee, Y., Lloyd, A. M., and Roux, S. J. 1999. Antisense expression of the CK2 alpha-subunit gene in Arabidopsis. Effects on light-regulated gene expression and plant growth. Plant Physiol. 119:989-1000.

Manning, V. A., Pandelova, I., and Ciuffetti, L. M. 2002. A race for a novel host-selective toxin. (Abstr.) Phytopathology 92:S51.

Manter, D. K. 2002. Energy dissipation and photoinhibition in Douglas-fir needles with a fungal-mediated reduction in photosynthetic rates. J. Phytopath. 150:674-679.

Martinez, J. P., Ottum, S. A., Ali, S., Francl, L. J., and Ciuffetti, L. M. 2001. Characterization of the ToxB gene from Pyrenophora triticirepentis. Mol. Plant-Microbe Interact. 14:675-677.

Martinez, J. P., Oesch, N. W., and Ciuffetti, L. M. 2004. Characterization of the multiple copy host-selective toxin gene, $\operatorname{Tox} B$, in pathogenic and nonpathogenic isolates of Pyrenophora tritici-repentis. Mol. PlantMicrobe Interact. in press.

Meinhardt, S. W., Cheng, W., Kwon, C. Y., Donohue, C. M., and Rasmussen, J. B. 2002. Role of the arginyl-glycyl-aspartic motif in the action of Ptr ToxA produced by Pyrenophora tritici-repentis. Plant Physiol. 130:1545-1551.

Mellersh, D. G., and Heath, M. C. 2001. Plasma membrane-cell wall adhesion is required for expression of plant defense responses during fungal penetration. Plant Cell 13:413-424.

Nagpal, P., and Quatrano, R. S. 1999. Isolation and characterization of a cDNA clone from Arabidopsis thaliana with partial sequence similarity to integrins. Gene 230:33-40.

Pinna, L. A. 1990. Casein kinase 2: an 'eminence grise' in cellular regulation? Biochim. Biophys. Acta 1054:267-284.

Redick, S. D., Settles, D. L., Briscoe, G., and Erickson, H. P. 2000. Defining fibronectin's cell adhesion synergy site by site-directed mutagenesis. J. Cell Biol. 149:521-527.

Reuzeau, C., and Pont-Lezica, R. F. 1995. Comparing plant and animal extracellular matrix-cytoskeleton connections-Are they alike? Protoplasma 186:113-121.

Ruoslahti, E., and Pierschbacher, M. D. 1986. Arg-Gly-Asp: A versatile cell recognition signal. Cell 44:517-518.

Sanders, D., Pelloux, J., Brownlee, C., and Harper, J. F. 2002. Calcium at the crossroads of signaling. Plant Cell 14:401-417.

Sanders, L. C., Wang, C. S., Walling, L. L., and Lord, E. M. 1991. A homolog of the substrate adhesion molecule vitronectin occurs in four species of flowering plants. Plant Cell 3:629-635.

Satterlee, J. S., and Sussman, M. R. 1998. Unusual membrane-associated protein kinases in higher plants. J. Membrane Biol. 164:205-213.

Schindler, M., Meiners, S., and Cheresh, D. A. 1989. RGD-dependent linkage between plant cell wall and plasma membrane: Consequences for growth. J. Cell Biol. 108:1955-1965.

Schvartz, I., Seger, D., and Shaltiel, S. 1999. Vitronectin. Int. J. Biochem. Cell Biol. 31:539-544.

Seger, D., Gechtman, Z., and Shaltiel, S. 1998. Phosphorylation of vitronectin by casein kinase II. Identification of the sites and their promotion of cell adhesion and spreading. J. Biol. Chem. 273:24805-24813.

Sigrist, C. J., Cerutti, L., Hulo, N., Gattiker, A., Falquet, L., Pagni, M., Bairoch, A., and Bucher, P. 2002. PROSITE: A documented database using patterns and profiles as motif descriptors. Brief Bioinformatics 3:265-274.
Stock, W. S., Brule-Babel, A. L., and Penner, G. A. 1996. A gene for resistance to a necrosis-inducing isolate of Pyrenophora tritici-repentis located on 5BL of Triticum aestivum cv. Chinese spring. Genome 39:598-604.

Strelkov, S., Lamari, L., Ballance, G. M., and Orolaza, N. P. 1998. Isolation and mode of action of PTR chlorosis toxin from Pyrenophora tritici-repentis. Pages 137-138 in: Molecular Genetics of Host-specific Toxins in Plant Disease. K. Kohmoto and O. C. Yoder, eds. Kluwer Academic Publishers, Dordrecht, The Netherlands.

Strelkov, S. E., Lamari, L., and Ballance, G. M. 1999. Characterization of a host-specific protein toxin (Ptr ToxB) from Pyrenophora tritici-repentis. Mol. Plant-Microbe Interact. 12:728-732.

Sugano, S., Andronis, C., Ong, M. S., Green, R. M., and Tobin, E. M. 1999. The protein kinase CK2 is involved in regulation of circadian rhythms in Arabidopsis. Proc. Natl. Acad. Sci. U.S.A. 96:1236212366.

Sun, Y., Qian, H., Xu, X. D., Han, Y., Yen, L. F., and Sun, D.Y. 2000. Integrin-like proteins in the pollen tube: detection, localization and function. Plant Cell Physiol. 41:1136-1142.

Suzuki, S., Oldberg, A., Hayman, E. G., Pierschbacher, M. D., and Ruoslahti, E. 1985. Complete amino acid sequence of human vitronectin deduced from cDNA. Similarity of cell attachment sites in vitronectin and fibronectin. EMBO (Eur. Mol. Biol. Organ.) J. 4:2519-2524.

Swatzell, L. J., Edelmann, R. E., Makaroff, C. A., and Kiss, J. Z. 1999. Integrin-like proteins are localized to plasma membrane fractions, not plastids, in Arabidopsis. Plant Cell Physiol. 40:173-183.

Tomas, A., Feng, G. H., Reeck, G. R., Bockus, W. W., and Leach, J. E. 1990. Purification of a cultivar-specific toxin from Pyrenophora triticirepentis, causal agent of tan spot of wheat. Mol. Plant-Microbe Interact. 3:221-224.

Towler, D. A., and Gordon, J. I. 1988. The biology and enzymology of eukaryotic protein acylation. Annu. Rev. Biochem. 57:69-99.

Towler, D. A., Eubanks, S. R., Towery, D. S., Adams, S. P., and Glaser, L. 1987. Amino-terminal processing of proteins by N-myristoylation. Substrate specificity of N-myristoyl transferase. J. Biol. Chem. 262:10301036.

Tuori, R. P., Wolpert, T. J., and Ciuffetti, L. M. 1995. Purification and immunological characterization of toxic components from cultures of Pyrenophora tritici-repentis. Mol. Plant-Microbe Interact. 8:41-48.

Tuori, R. P., Wolpert, T. J., and Ciuffetti, L. M. 2000. Heterologous expression of functional Ptr ToxA. Mol. Plant-Microbe Interact. 13:456464.

van der Most, R. G., Corver, J., and Strauss, J. H. 1999. Mutagenesis of the RGD motif in the yellow fever virus 17D envelope protein. Virology 265:83-95.

Walton, J. D. 1996. Host-selective toxins: Agents of compatibility. Plant Cell 8:1723-1733.

Wang, D., Harper, J. F., and Gribskov, M. 2003. Systematic trans-genomic comparison of protein kinases between Arabidopsis and Saccharomyces cervisiae. Plant Physiol. 132:2152-2165.

Wilcox, C., Hu, J. S., and Olson, E. N. 1987. Acylation of proteins with myrisitic acid occurs cotranslationally. Science 238:1275-1278.

Wolpert, T. J., Dunkle, L. D., and Ciuffetti, L. M. 2002. Host-selective toxins and avirulence determinants: What's in a name? Annu. Rev. Phytopathol. 40:251-285.

Woodgett, J. R., Gould, K. L., and Hunter, T. 1986. Substrate specificity of protein kinase $\mathrm{C}$. Use of synthetic peptides corresponding to physiological sites as probes for substrate recognition requirements. Eur. J. Biochem. 161:177-184.

Zha, J., Weiler, S., Oh, K. J., Wei, M. C., and Korsmeyer, S. J. 2000. Posttranslational N-myristoylation of BID as a molecular switch for targeting mitochondria and apoptosis. Science 290:1761-1765.

Zhang, H., Francl, L. J., Jordahl, J. G., and Meinhardt, S. W. 1997. Structural and physical properties of a necrosis-inducing toxin from Pyrenophora tritici-repentis. Phytopathology 87:154-160.

Zhu, J. K., Damsz, B., Kononowicz, A. K., Bressan, R. A., and Hasegawa, P. M. 1994. A higher plant extracellular vitronectin-like adhesion protein is related to the translational elongation factor-1 alpha. Plant Cell 6:393-404. 